\title{
ANALISIS RASIO LIKUIDITAS RASIO SOLVABILITAS DAN RASIO PROFITABILITAS DALAM MENGUKUR KINERAJA KEUANGAN PT BANK RAKYAT INDONESIA Tbk Periode 2011-2020
}

\author{
Izzatun Nisa \\ Mahasiswa Fakultas Ekonomi dan Bisnis Universitas Pamulang \\ email : izzatunn421@gmail.com \\ Aria Aji Priyanto \\ Dosen Fakultas Ekonomi dan Bisnis Universitas Pamulang \\ email : dosen01048@unpam.ac.id
}

\begin{abstract}
ABSTRAK
Riset ini mempunyai tujuan mengenali ikatan antara likuiditas, solvabilitas dan profitabilitas buat mengukur kinerja keuangan PT Bank Rakyat Indonesia Tbk periode 2011-2020. Tata cara yang digunakan merupakan deskriptif serta kuantitatif. Hasilnya bisa dibanding dengan standar industri perbankan Indonesia, yang bisa memastikan status industri. Hasil riset menampilkan kalau kinerja keuangan PT Bank Rakyat Indonesia Tbk selama 10 (sepuluh) tahun dari tahun 2011-2020. Hasil dalam riset ini merupakan hasil Analisis Kinerja keuangan yang diukur lewat Rasio Likuiditas dengan memakai Current ratio, Cash ratio, LDR dan LAR dinyatakan sehat karena bisa lebih dari Standar Industri Bank Indonesia, sedangkan pada Rasio Solvabilitas dengan menggunakan Primary Ratio,DAR,CAR dinyatakan sehat sebaliknya Secondary Risk Ratio dikatakan kurang sehat sebab kurang dari standar industri Bank Indonesia, serta pada Analisis Rasio Profitabilitas dengan memakai ROA, ROE, NIM dinyatakan sehat, sebaliknya pada nilai BOPO dinyatakan kurang sehat sebab melebihi standar kentuan Bank Indonesia.
\end{abstract}

Kata kunci : Rasio Likuiditas, Rasio Solvabilitas,Rasio Profitabilitas, dan Kinerja Keuangan

\section{ABSTRACT}

This study aims to determine the ratio of liquidity, solvency and profitability in measuring the financial performance of PT Bank Rakyat Indonesia Tbk for the period 2011-2020. The method used is descriptive quantitative. Results that can be compared with Bank Indonesia industry standards that can determine the company's performance conditions. The results show that the financial performance of PT Bank Rakyat Indonesia Tbk for 10 (ten) years from 2011-2020. The results in this study are the results of the Financial Performance Analysis measured through the Liquidity Ratio using the Current ratio, Cash ratio, LDR and LAR are declared healthy because they exceed the Industrial Standards of Bank Indonesia, while the Solvency Ratio using the Primary Ratio, DAR, CAR is declared healthy while The Secondary Risk Ratio is said to be unhealthy because it is less than the industry standard of Bank Indonesia, and the Profitability Ratio Analysis using ROA, ROE, NIM is declared healthy, while the BOPO value is declared unhealthy because it exceeds the standards stipulated by Bank Indonesia

Keywords: Liquidity Ratio, Solvability Ratio, Profitability Ratio and Financial Performance 


\section{PENDAhUluAN}

\section{A. Latar Belakang}

Perbankan merupakan salah satu lembaga atau perusahaan yang menangani bidang perekonomian suatu negara, khususnya dalam bidang keuangan dan ekonomi.

Dunia yang semakin maju menutut perbankan untuk lebih ber inovasi dan memiliki kualitas yang baik untuk dapat menghadapi persaingan. Analisis keuangan penting dilakukan supaya sumber daya dapat digunakan untuk menghadapi adanya lingkungan yang berubah. Sehingga perusahaan dapat mempertimbangkan dalam pengambilan keputusan dan perencanaan dimasa mendatang guna mencapai tujuan.

Menurut Prastowo dan Julianty (2010:56), analisis laporan keuangan tahunan dianggap ini bisa membantu untuk mengevaluasi kinerja keuangan perusahaan, dan tujuan utamanya yaitu menentukan perkiraan serta prakiraan dan hasil perusahaan di masa depan.

Hal-hal yang dapat mengukur kinerja keuangan dapat dijelaskan melalui beberapa rasio yaitu rasio likuiditas, rasio solvabilitas dan rasio Profitabilitas

Menurut Kasmir (2015:130) rasio Likuiditas merupakan ukuran likuiditas perusahaan. Caranya adalah dengan membandingkan total aset, total aset lancar, dan total kewajiban jangka pendek (short-term debt). Valuasi dapat dilakukan dalam periode waktu yang berbeda untuk melacak perubahan likuiditas setiap saat.

$$
\text { Menurut Kasmir (2015:151), }
$$

leverage adalah angka kunci yang mengukur sejauh mana aset perusahaan dibiayai oleh modal eksternal, yaitu berapa banyak utang yang dimiliki perusahaan terkait dengan asetnya.

Menurut Kasmir (2015:196), indeks profitabilitas adalah ukuran kemampuan perusahaan untuk menciptakan laba. Indeks tersebut juga dapat digunakan untuk mengukur kinerja corporate governance. Hal ini bisa diketahui dengan keuntungan penjualan dan pendapatan investasi.

Penelitian ini bertujuan untuk mengukur kinerja keuangan selama periode waktu tertentu. Selain itu, penelitian ini dilakukan untuk memberikan informasi tentang kekuatan dan kelemahan perusahaan, karena manajemen memahami kelemahan tersebut dan dapat memperbaikinya. Kemudian dengan mengetahui kekuatan yang dimiliki perusahaan bisa mempertahankan atau bahkan meningkatkan kekuatan yang dimiki sebagai modal keberlangsungan perusahaan kedepannya yang lebih baik. Mengingat kekuatan dan kelemahannya, efektivitas kepemimpinan telah ditunjukkan sejauh ini.

Berdasarkan hal tersebut, penulis tertarik menggunakan kinerja keuangan perusahaan untuk mempelajari indikator keuangan karena penulis ingin mengetahui analisis indikator keuangan yang digunakan sebagai estimasi kinerja keuangan PT Bank Rakyat Indonesia Tbk dengan judul "Analisis Rasio Likuiditas Rasio Solvabilitas dan Rasio Profitabilitas Dalam mengukur Kinerja Keuangan PT Bank Rakyat Indonesia Tbk Periode 20112020"

\section{B. Rumusan Masalah.}

1. Bagaimana Rasio Likuidatas pada PT Bank Rakyat Indonesia Tbk selama periode 2011-2020?

2. Bagaimana Rasio Solvabilitas pada PT Bank Rakyat Indonesia Tbk selama periode 2011-2020?

3. Bagaimana Rasio Profitabilitas pada PT Bank Rakyat Indonesia Tbk selama periode 2011-2020?

4. Bagaimana Kinerja Keuangan PT Bank Rakyat Indonesia Tbk selama periode 2011-2020?

\section{Tujuan Penelitian}

1. Untuk mengetahui tingakat Rasio Likuiditas PT Bank Rakyat Indonesia Tbk Periode 2011-2020. 
2. Untuk mengetahui tingakat Rasio Solvabilitas PT Bank Rakyat Indonesia Tbk Periode 2011-2020

3. Untuk mengetahui tingakat Rasio Solvabilitas PT Bank Rakyat Indonesia Tbk Periode 2011-2020

4. Untuk mengetahui Kinerja Keuangan PT Bank Rakyat Indonesia Tbk Periode 2011-2020

\section{TINJAUAN PUSTAKA}

\section{A. Manajemen Keuangan}

Menurut Irham Fahmi (2011:12), manajemen keuangan adalah kegiatan merencanakan, menganggarkan, menyelidiki, mengelola, mengendalikan, menanyakan dan menyimpan dana suatu organisasi atau perusahaan.

Menurut Sutrisno (2012:3), manajemen keuangan yaitu segala kegiatan perusahaan, dalam kegiatan tersebut, suatu usaha untuk menghimpun dana dari perusahaan dan biayanya rendah untuk menggunakan dan mengalokasikan dana tersebut secara efektif.

Menurut Kamaludin (2011): 1) Ini adalah upaya untuk mengumpulkan dan mendistribusikan dana dengan cara yang paling menguntungkan. Beroperasi secara efisien di perusahaan untuk mencapai tujuan pemegang saham.

Dari definisi-definisi sebelumnya, dapat diambil kesimpulan yaitu manajemen keuangan mencakup semua kegiatan perusahaan, yang juga mencakup pencarian sumber daya ekonomi perusahaan serta penggunaan dan alokasi sumber daya tersebut secara efektif.

\section{B. Fungsi Manajemen Keuangan}

Menurut Sutrisno (2012:5), fungsi manajemen yaitu:

1) Keputusan investasi

Cara manajer keuangan mengalokasikan dana dengan bentuk investasi yang bisa menghasilkan pendapatan di masa depan. Disertai dengan banyak risiko atau ketidakpastian. Risiko dan hasil yang diharapkan dari investasi ini akan memiliki dampak yang signifikan terhadap pelaksanaan kebijakan dan tujuan penilaian perusahaan.

2) Keputusan Pembiayaan Manajer keuangan harus meninjau dana dan menganalisis portofolio sumber daya perusahaan yang tersedia untuk memenuhi kebutuhan bisnis dan investasinya.

3) Keputusan dividen

Keputusan keuangan untuk menentukan keuntungan yang dibagikan ke pemegang saham (berupa dividen tunai, stabilitas pembagian dividen, dividen per saham), pemecahan saham, dan keuntungan beredar saham yang bertujuan untuk meningkatkan aset pemegang saham.

\section{Kinerja Keuangan}

Rudianto(2013:189)mendefinisikan efisiensi sebagai hasil yang diperoleh manajemen suatu perusahaan dalam menjalankan fungsinya untuk mengelola aset perusahaan secara efektif dalam jangka waktu tertentu.

Menurut Irham Fahmi (2013:239) yaitu analisis yang digunakan untuk mengetahui apakah perusahaan telah menerapkan aturan kinerja keuangan secara benar dan tepat.

Kesimpulannya adalah kinerja keuangan merupakan analisis yang dinilai dalam bentuk efektifitas operasional yang dapat dilihat dari segi manajemen dan prestasi pada perusahaan tersebut.

\section{Perbankan}

Menurut Kasmir (2014:24) bank yaitu lembaga keuangan yang kegiatanya mengumpulkan dan menyalurkan dana dari masyarakat, dan memberi jasa bank lainnya. Bank adalah organisasi perdagangan yang mengkhususkan diri dalam keuangan atau jasa keuangan, dan produk utama mereka biasanya giro, tabungan dan deposito berjangka.

Dari sebagian penafsiran diatas hingga bisa simpulkan kalau lembaga keuangan 
yang kegiatanya menghimpun dana dari warga dalam wujud simpanan setelah itu meyalurkan kembali kepada warga bank pula digunakan selaku tempat buat simpan pinjam ataupun kredit untuk masyarakat warga yang memerlukan dana pinjaman.

\section{E. Rasio Likuiditas}

Bagi Kasmir( 2015: 130) rasio likuiditas ialah rasio yang digunakan buat mengukur seberapa likuidnya sesuatu industri”. Triknya ialah mebandingkan, total aktiva mudah dengan total pasiva mudah( utang jangka pendek) Adapun rasio-rasio dalam penelitian ini adalah :

1) Current Ratio

2) Cash Ratio

3) LDR

4) LAR

\section{F. Rasio Solvabilitas}

Bagi Kasmir( 2015: 151) rasio solvabilitas ataupun leverage ratio ialah indeks yang digunakan buat mengukur sepanjang mana peninggalan industri dibiayai oleh utang. Maksudnya berapa besar beban utang yang ditanggung industri dibanding dengan aktivanya.

Adapun rasio -rasio dalam penelitian ini adalah :

1) Primary ratio

2) Secondary risk ratio

3) DAR

4) CAR

\section{G. Rasio Profitabilitas}

Bagi Kasmir( 2015: 196) rasio profitabilitas ialah memperhitungkan profitabilitas industri. Memakai penanda buat mengevaluasi daya guna manajemen industri. Perihal ini bisa dibuktikan dari keuntungan penjualan serta pemasukan investasi. Sementara itu, pemakaian koefisien ini menampilkan daya guna industri. Adapun rasio-rasio dalam penelitian ini adalah :
1) $\mathrm{ROA}$
2) ROE
3) NIM
4) $\mathrm{BOPO}$

\section{METODE PENELITIAN}

Tempat dilakukannya penelitain adalah di PT Bank Rakyat Indonesia Tbk periode 2011 sampai 2020 yang diperoleh dari situs resmi di antara lembaga yang terkait langsung dengan kegiatan pasar modal adalah Pusat Informasi Pasar Modal (PIPM) yang merupakan perwakilan dari Bursa Efek Indonesia (BEI) yang terletak di Gedung Bursa Efek Jakarta sisi Tower 2, 1. Jl. Chandraal Su Diman Kraft 5253, Senayan, Kebayoran Baru, Jakarta Selatan 12190, dapat dilihat di www.idx.co.id dan website resmi PT Bank Rakyat Indonesia Tbk www.bri.co.id

Metode penelitian ini yaitu deskriptif kuantitatif yaitu melakukan penelitian dan pembahasan berdasarkan teori-teori dan penelitian yang sama mendahuluinya yang menggambarkan keuangan perusahaan yaitu Analisis Rasio Likuiditas, Rasio Solvabilitas, dan Rasio Profitabilitas yang dinyatakan dalam bentuk data-data yang bersifat angka.

Menurut Sugiyono (2016:80), populasi yaitu wilayah generalisasi atas objek dan subjek yang memiliki karakteristik unik dan ditetapkan peneliti untuk dipelajari kemudian ditarik kesimpulannya. Populasi penelitian ini yaitu seluruh laporan keuangan perusahaan PT Bank Rakyat Indonesia Tbk.

Menurut Sugiyono (2010:116), sampel yaitu bagian dari ukuran dan sifat umum. Peneliti tidak dapat mempelajari semua isi dalam kelompok, seperti keterbatasan sumber daya, tenaga, dan waktu, peneliti bisa menggunakan sampel kelompok. Oleh karena itu, sampel dari populasi umum perlu benar-benar representatif. Sampel yang digunakan dalam penelitian ini adalah neraca dan laporan laba rugi tahun 2011-2020 PT Bank Rakyat Indonesia Tbk.

\section{HASIL DAN PEMBAHASAN A. Gambaran Objek Penelitian}


Berbagai nama telah diberikan pada BRI, mulai dari De Poerwokertosche Hulp en Spaarbank der Indlandsche Hoofden, Hulp en Spaarbank der Indlandsche Bestuurs Ambtenareen, Syomin Ginko, dan diresmikan sebagai Bank Rakyat Indonesia sesuai dengan UU Nomor 21 Tahun 1968 pada 18 Desember 1968. Pada tahun 1992, berdasarkan Undang-Undang Perbankan No. 7 Tahun 1992, BRI berubah status hukum menjadi PT Bank Rakyat Indonesia (Persero) dan tercatat di Bursa Efek Jakarta (sekarang Bursa Efek Indonesia). 10 November 2003, kode gudang BBRI.

\section{B. Pembahasan dan Hasil Penelitian}

\section{Rasio Likuiditas}

a. Current ratio

$\mathrm{CRR}=$ Aktiva Lancar $\mathrm{x}$ 100\% Hutang Lancar

Perhitungan Current ratio BRI 2011-2020

\begin{tabular}{|l|l|l|l|}
\hline $\begin{array}{l}\text { Tahu } \\
\text { n }\end{array}$ & $\begin{array}{l}\text { Aktiva } \\
\text { Lanca } \\
\text { r }\end{array}$ & $\begin{array}{l}\text { Hutang } \\
\text { Lancar }\end{array}$ & CRR \\
\hline 2011 & $\begin{array}{l}285.40 \\
6.257\end{array}$ & $\begin{array}{l}384.264 .3 \\
45\end{array}$ & $\begin{array}{l}74,23 \\
\%\end{array}$ \\
\hline 2012 & $\begin{array}{l}350.75 \\
8.262\end{array}$ & $\begin{array}{l}450.166 .3 \\
83\end{array}$ & $\begin{array}{l}77,91 \\
\%\end{array}$ \\
\hline 2013 & $\begin{array}{l}430.61 \\
7.873\end{array}$ & $\begin{array}{l}486.366 .3 \\
71\end{array}$ & $\begin{array}{l}88,53 \\
\%\end{array}$ \\
\hline 2014 & 490.40 & 600.404 .3 & $\begin{array}{l}86,67 \\
\%\end{array}$ \\
\hline 2.708 & 70 & $\begin{array}{l}86,87 \\
\%\end{array}$ \\
\hline 2015 & $\begin{array}{l}558.43 \\
6.016\end{array}$ & $\begin{array}{l}642.774 .0 \\
04\end{array}$ & $\begin{array}{l}83.29 \\
\%\end{array}$ \\
\hline 2016 & $\begin{array}{l}723.845 .4 \\
58\end{array}$ & $\begin{array}{l}87,76 \\
\%\end{array}$ \\
\hline 2017 & $\begin{array}{l}708.00 \\
1.045\end{array}$ & $\begin{array}{l}803.326 .5 \\
70\end{array}$ \\
\hline 2018 & 798.88 & $\begin{array}{l}898.032 .5 \\
64\end{array}$ & $\begin{array}{l}88,95 \\
\%\end{array}$ \\
\hline & 1.042 & & \\
\hline
\end{tabular}

\begin{tabular}{|l|l|l|l|}
\hline 2019 & $\begin{array}{l}859.55 \\
8.294\end{array}$ & $\begin{array}{l}969.750 .0 \\
06\end{array}$ & $\begin{array}{l}88,63 \\
\%\end{array}$ \\
\hline 2020 & $\begin{array}{l}880.67 \\
4.757\end{array}$ & $\begin{array}{l}1.052 .663 . \\
870\end{array}$ & $\begin{array}{l}83,66 \\
\%\end{array}$ \\
\hline Min & $\begin{array}{l}\mathbf{2 8 5 . 4 0} \\
\mathbf{6 . 2 5 7}\end{array}$ & $\begin{array}{l}\mathbf{3 8 4 . 2 6 4 . 3} \\
\mathbf{4 5}\end{array}$ & $\begin{array}{l}\mathbf{7 4 , 2 3} \\
\mathbf{\%}\end{array}$ \\
\hline Mean & $\begin{array}{l}\mathbf{5 9 9 . 8 0} \\
\mathbf{2 . 7 4 7}\end{array}$ & $\mathbf{7 0 1 . 1 5 9 . 3}$ & $\begin{array}{l}\mathbf{8 6 , 4 2} \\
\mathbf{9 4}\end{array}$ \\
\hline Max & $\begin{array}{l}\mathbf{8 8 0 . 6 7} \\
\mathbf{4 . 7 5 7}\end{array}$ & $\begin{array}{l}\mathbf{1 . 0 5 2 . 6 6 3} . \\
\mathbf{8 7 0}\end{array}$ & $\begin{array}{l}\mathbf{8 8 , 9 5} \\
\mathbf{\%}\end{array}$ \\
\hline
\end{tabular}

Bedasarkan tabel diatas dapat disimpulkan bahwa nilai current ratio tertinggi ( $\max$ ) perusahaan terjadi pada tahun 2018 yaitu sebesar $88,95 \%$. Hal ini berarti dengan aset yang dimiliki perusahaan maka perusahaan mampu memanfaatkan aset-asetnya dengan baik sehingga dapat mengukur kemampuan perusahaan untuk melunasi kewajiban jangka pendeknya. Nilai current ratio terendah ( $\mathrm{min}$ ) terjadi pada tahun 2011 yaitu sebesar 74,23\%. Hal ini dikarenakan perusahaan masih belum bisa memaksimalkan penggunaan aset yang dimilikinya. Rendahnya nilai current ratio pada tahun 2011 disebabkan karena hutang lancar terhadap aset lancar yang dimiliki perusahaan meningkat sehingga beban aset lancar terhadap hutang perusahaan meningkat. Nilai Current Ratio pada rata-rata (mean) perusahaan adalah sebesar $86,42 \%$, hal ini menunjukan bahwa current ratio pada PT Bank Rakyat Indonesia Tbk dapat menutupi kewajiban jangka pendeknya.

\section{b. Cash ratio}

$\mathrm{CR}=$ Kas+ Efek $\times 100 \%$

Hutang Lancar

Perhitungan Cash Ratio BRI

Tahun 2011-2020

\begin{tabular}{|c|c|c|c|}
\hline $\begin{array}{c}\text { Tah } \\
\text { un }\end{array}$ & $\begin{array}{c}\text { Kas + } \\
\text { Efek }\end{array}$ & $\begin{array}{c}\text { Hutang } \\
\text { Lancar }\end{array}$ & $\begin{array}{c}\text { Cash } \\
\text { Ratio }\end{array}$ \\
\hline
\end{tabular}


JRNAL ПMПAH

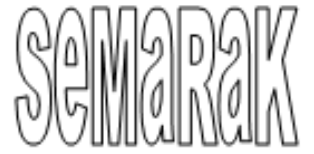

P-ISSN 2615-6849, E-ISSN 2622-3686

Jurnal Semarak,Vol.4,No.3,Oktober 2021, Hal (55- 69)

\begin{tabular}{|c|c|c|c|}
\hline 2011 & $\begin{array}{c}43.566 . \\
391\end{array}$ & $\begin{array}{c}384.264 .3 \\
45\end{array}$ & $\begin{array}{c}11,33 \\
\%\end{array}$ \\
\hline 2012 & 590 & $\begin{array}{c}450.166 .3 \\
83\end{array}$ & $\begin{array}{c}12,53 \\
\%\end{array}$ \\
\hline 2013 & $\begin{array}{c}58.924 . \\
132\end{array}$ & $\begin{array}{c}486.366 .3 \\
71\end{array}$ & $\begin{array}{c}12,11 \\
\%\end{array}$ \\
\hline 2014 & $\begin{array}{c}72.120 . \\
149\end{array}$ & $\begin{array}{c}600.404 .3 \\
70\end{array}$ & $\begin{array}{c}12,01 \\
\%\end{array}$ \\
\hline 2015 & $\begin{array}{c}88.599 . \\
130\end{array}$ & $\begin{array}{c}642.774 .0 \\
04\end{array}$ & $\begin{array}{c}13,78 \\
\%\end{array}$ \\
\hline 2016 & $\begin{array}{c}78.263 . \\
373\end{array}$ & $\begin{array}{c}723.845 .4 \\
58\end{array}$ & $\begin{array}{c}10,81 \\
\%\end{array}$ \\
\hline 2017 & 595 & $\begin{array}{c}803.326 .5 \\
70\end{array}$ & $\begin{array}{c}9,96 \\
\%\end{array}$ \\
\hline 2018 & $\begin{array}{c}95.788 . \\
043\end{array}$ & $\begin{array}{c}898.032 .5 \\
64\end{array}$ & $\begin{array}{c}10,66 \\
\%\end{array}$ \\
\hline 2019 & $\begin{array}{c}98.739 . \\
471\end{array}$ & $\begin{array}{c}969.750 .0 \\
06\end{array}$ & $\begin{array}{c}10,18 \\
\%\end{array}$ \\
\hline 2020 & $\begin{array}{c}80.711 . \\
217\end{array}$ & $\begin{array}{c}1.052 .663 . \\
870\end{array}$ & $\begin{array}{c}7,66 \\
\%\end{array}$ \\
\hline Min & $\begin{array}{c}43.566 . \\
391\end{array}$ & $\begin{array}{c}384.264 .3 \\
45\end{array}$ & $\begin{array}{c}7,66 \\
\%\end{array}$ \\
\hline $\begin{array}{c}\text { Mea } \\
\mathbf{n}\end{array}$ & $\begin{array}{c}75.316 . \\
709\end{array}$ & $\begin{array}{c}701.159 .3 \\
94\end{array}$ & $\begin{array}{c}11,10 \\
\%\end{array}$ \\
\hline Max & $\begin{array}{c}98.739 . \\
471\end{array}$ & $\begin{array}{c}1.052 .663 . \\
870\end{array}$ & $\begin{array}{c}13,78 \\
\%\end{array}$ \\
\hline
\end{tabular}

Bedasarkan tabel diatas dapat disimpulkan bahwa nilai cash ratio tertinggi terjadi pada 2015 sebesar 13,78\%. Hal ini menunjukkan perusahaan bisa memanfaatkan kasnya secara baik dan dapat mengukur kemampuan perusahaan dalam melunasi utang jangka pendeknya. Nilai cash ratio terendah (min) terjadi pada tahun 2020 yaitu sebesar 7,66\%. Cash Ratio pada rata-rata (mean) perusahaan adalah sebesar $11,10 \%$, hal ini menjelaskan cash ratio pada
PT Bank Rakyat Indonesia Tbk dapat menutupi kewajiban jangka pendeknya.

c. LDR

Kredit yang diberikan x 100\%

Dana yang diterima

Perhitungan LDR BRI

Tahun 2011-2020

\begin{tabular}{|c|c|c|c|}
\hline $\begin{array}{c}\text { Tah } \\
\text { un }\end{array}$ & $\begin{array}{c}\text { Kredit } \\
\text { yang } \\
\text { diberika } \\
\text { n }\end{array}$ & $\begin{array}{l}\text { Dana } \\
\text { yang } \\
\text { diterima }\end{array}$ & LDR \\
\hline 2011 & $\begin{array}{c}285.406 \\
257\end{array}$ & $\begin{array}{c}384.264 .3 \\
45\end{array}$ & $\begin{array}{c}74,27 \\
\%\end{array}$ \\
\hline 2012 & $\begin{array}{c}350.758 \\
262\end{array}$ & $\begin{array}{c}450.166 .3 \\
83\end{array}$ & $\begin{array}{c}77,91 \\
\%\end{array}$ \\
\hline 2013 & $\begin{array}{c}430.617 \\
873\end{array}$ & $\begin{array}{c}486.366 .3 \\
71\end{array}$ & $\begin{array}{c}88,53 \\
\%\end{array}$ \\
\hline 2014 & $\begin{array}{c}490.402 . \\
708\end{array}$ & $\begin{array}{c}600.404 .3 \\
70\end{array}$ & $\begin{array}{c}81,67 \\
\%\end{array}$ \\
\hline 2015 & $\begin{array}{c}558.436 . \\
016\end{array}$ & $\begin{array}{c}642.774 .0 \\
04\end{array}$ & $\begin{array}{c}86,87 \\
\%\end{array}$ \\
\hline 2016 & $\begin{array}{c}635.291 \\
221\end{array}$ & $\begin{array}{c}723.845 .4 \\
58\end{array}$ & $\begin{array}{c}87,76 \\
\%\end{array}$ \\
\hline 2017 & $\begin{array}{c}708.001 . \\
045\end{array}$ & $\begin{array}{c}803.326 .5 \\
70\end{array}$ & $\begin{array}{c}88,13 \\
\%\end{array}$ \\
\hline 2018 & $\begin{array}{c}798.881 . \\
042\end{array}$ & $\begin{array}{c}898.032 .5 \\
64\end{array}$ & $\begin{array}{c}88,95 \\
\%\end{array}$ \\
\hline 2019 & $\begin{array}{c}859.558 . \\
294\end{array}$ & $\begin{array}{c}969.750 .0 \\
06\end{array}$ & $\begin{array}{c}88,63 \\
\%\end{array}$ \\
\hline 2020 & $\begin{array}{c}880.674 . \\
757\end{array}$ & $\begin{array}{c}1.052 .663 . \\
870\end{array}$ & $\begin{array}{c}83,66 \\
\%\end{array}$ \\
\hline Min & \begin{tabular}{|c|}
285.406. \\
257
\end{tabular} & $\begin{array}{c}384.264 .3 \\
45\end{array}$ & $\begin{array}{c}74,27 \\
\%\end{array}$ \\
\hline $\begin{array}{c}\text { Mea } \\
\text { n }\end{array}$ & $\begin{array}{c}599.802 . \\
747\end{array}$ & $\begin{array}{c}701.159 .3 \\
94\end{array}$ & $\begin{array}{c}84,63 \\
\%\end{array}$ \\
\hline Max & $\begin{array}{c}880.674 . \\
757\end{array}$ & $\begin{array}{c}\text { 1.052.663. } \\
870\end{array}$ & $\begin{array}{c}88,95 \\
\%\end{array}$ \\
\hline
\end{tabular}


Seperti yang terlihat dari tabel di atas, suku bunga simpanan dan pinjaman (maks) perusahaan pada tahun 2018 merupakan yang tertinggi yaitu sebesar $88,95 \%$. Indeks simpanan dan pinjaman terendah (terendah) terjadi pada tahun 2011, yaitu sebesar $74,27 \%$. Perusahaan belum bisa memanfaatkan sepenuhnya dana yang diterima. Rata-rata (rata-rata) nilai loan/deposit ratio korporasi adalah $84,63 \%$, yang menunjukkan loan/deposit ratio PT Bank Rakyat Indonesia Tbk dapat memberikan jumlah kredit kepada para nasabah dengan baik sehingga kelancaran operasional perusahaan dapat berjalan dengan lancar

d. LAR

LAR $=\underset{\text { Total Loans } x}{\text { Total Assets }}$

Perhitungan LAR BRI

Tahun 2011-2020

\begin{tabular}{|l|c|c|c|}
\hline $\begin{array}{l}\text { Tah } \\
\text { un }\end{array}$ & $\begin{array}{c}\text { Total } \\
\text { Loans }\end{array}$ & $\begin{array}{c}\text { Total } \\
\text { Assets }\end{array}$ & LAR \\
\hline 2011 & $\begin{array}{c}384.264 .3 \\
45\end{array}$ & $\begin{array}{c}469.899 .2 \\
84\end{array}$ & $\begin{array}{c}81,77 \\
\%\end{array}$ \\
\hline 2012 & $\begin{array}{c}450.166 .3 \\
83\end{array}$ & $\begin{array}{c}551.336 .7 \\
90\end{array}$ & $\begin{array}{c}81,64 \\
\%\end{array}$ \\
\hline 2013 & $\begin{array}{c}486.366 .3 \\
71\end{array}$ & $\begin{array}{c}606.370 .2 \\
42\end{array}$ & $\begin{array}{c}80,20 \\
\%\end{array}$ \\
\hline 2014 & $\begin{array}{c}600.404 .3 \\
70\end{array}$ & $\begin{array}{c}778.046 .0 \\
85\end{array}$ & $\begin{array}{c}77,16 \\
\%\end{array}$ \\
\hline 2015 & $\begin{array}{c}642.774 .0 \\
04\end{array}$ & $\begin{array}{c}845.998 .3 \\
79\end{array}$ & $\begin{array}{c}75,97 \\
\%\end{array}$ \\
\hline 2016 & 723.845 .4 & 964.000 .6 & 75,08 \\
& 58 & 90 & $\%$ \\
\hline 2017 & 803.326 .5 & 1.076 .438 & 74,62 \\
& 70 & .066 & $\%$ \\
\hline 2018 & 898.032 .5 & 1.234 .200 & 72,76 \\
& 64 & .039 & $\%$ \\
\hline
\end{tabular}

\begin{tabular}{|c|c|c|c|}
\hline 2019 & $\begin{array}{c}969.750 .0 \\
06\end{array}$ & $\begin{array}{c}1.343 .077 \\
.860\end{array}$ & $\begin{array}{c}72,20 \\
\%\end{array}$ \\
\hline 2020 & $\begin{array}{c}1.052 .663 \\
.870\end{array}$ & $\begin{array}{c}1.421 .785 \\
.007\end{array}$ & $\begin{array}{c}74,03 \\
\%\end{array}$ \\
\hline Min & $\begin{array}{c}\mathbf{3 8 4 . 2 6 4 . 3} \\
\mathbf{4 5}\end{array}$ & $\begin{array}{c}\mathbf{4 6 9 . 8 9 9 . 2} \\
\mathbf{8 4}\end{array}$ & $\begin{array}{c}\mathbf{7 2 , 2 0} \\
\mathbf{\%}\end{array}$ \\
\hline $\begin{array}{c}\text { Mea } \\
\mathbf{n}\end{array}$ & $\begin{array}{c}\mathbf{7 0 1 . 1 5 9 . 3} \\
\mathbf{9 4}\end{array}$ & $\begin{array}{c}\mathbf{9 2 9 . 1 1 5 . 2} \\
\mathbf{4 4}\end{array}$ & $\begin{array}{c}\mathbf{7 6 , 5 4} \\
\mathbf{\%}\end{array}$ \\
\hline $\begin{array}{c}\text { Max } \\
\mathbf{1 . 0 5 2 . 6 6 3} \\
\mathbf{8 7 0}\end{array}$ & $\begin{array}{c}\mathbf{1 . 4 2 1 . 7 8 5} \\
\mathbf{. 0 0 7}\end{array}$ & $\begin{array}{c}\mathbf{8 1 , 7 7} \\
\mathbf{\%}\end{array}$ \\
\hline
\end{tabular}

Dapat disimpulkan dari tabel di atas bahwa rasio loan to assets (max) tertinggi muncul pada tahun 2011, yaitu sebesar $81,77 \%$, yang berarti seluruh aset yang dimiliki perusahaan dapat menggunakan asetnya dengan benar. Tingginya nilai Loan to Assets Ratio pada tahun 2013 disebabkan karena total aset yang yang lebih tinggi dari tahun-tahun sebelumnya. Nilai Loan to Assets Ratio terendah ( $\mathrm{min}$ ) terjadi pada tahun 2019 yaitu sebesar 72,20\%. Hal ini dikarenakan perusahaan masih belum bisa memaksimalkan penggunaan aset yang dimilikinya. Nilai Loan to Assets Ratio pada rata-rata (mean) perusahaan adalah sebesar $76,54 \%$, hal ini menunjukan bahwa Loan to Assets Ratio pada PT Bank Rakyat Indonesia Tbk dapat menyalurkan jumlah kredit kepada para nasabah dengan baik maka dengan itu perusahaan dapat menjalankan operasional perusahaan dengan lancar dan baik.

\section{Rasio Solvabilitas}

a. Primary Ratio

Equity Capital x $100 \%$

Perhitungan PR BRI

Tahun 2011-2020

\begin{tabular}{|c|c|c|c|}
\hline $\begin{array}{c}\text { Tah } \\
\text { un }\end{array}$ & $\begin{array}{l}\text { Equity } \\
\text { Capital }\end{array}$ & $\begin{array}{c}\text { Total } \\
\text { Aset }\end{array}$ & $\begin{array}{c}\text { Prim } \\
\text { ary }\end{array}$ \\
\hline
\end{tabular}


JRNAL ПMПAH

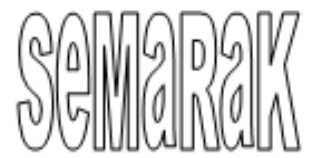

P-ISSN 2615-6849, E-ISSN 2622-3686

Jurnal Semarak,Vol.4,No.3,Oktober 2021, Hal (55- 69)

\begin{tabular}{|c|c|c|c|}
\hline & & & Ratio \\
\hline 2011 & $\begin{array}{c}49.820 .3 \\
29\end{array}$ & $\begin{array}{c}469.899 .2 \\
84\end{array}$ & $\begin{array}{c}10,60 \\
\%\end{array}$ \\
\hline 2012 & $\begin{array}{c}64.881 .7 \\
79\end{array}$ & $\begin{array}{c}551.336 .7 \\
90\end{array}$ & $\begin{array}{c}11,76 \\
\%\end{array}$ \\
\hline 2013 & $\begin{array}{c}78.869 .9 \\
16\end{array}$ & $\begin{array}{c}606.370 .2 \\
42\end{array}$ & $\begin{array}{c}13,00 \\
\%\end{array}$ \\
\hline 2014 & $\begin{array}{c}97.180 .9 \\
86\end{array}$ & $\begin{array}{c}778.046 .0 \\
85\end{array}$ & $\begin{array}{c}12,49 \\
\%\end{array}$ \\
\hline 2015 & $\begin{array}{c}112.391 . \\
798\end{array}$ & $\begin{array}{c}845.998 .3 \\
79\end{array}$ & $\begin{array}{c}13,28 \\
\%\end{array}$ \\
\hline 2016 & $\begin{array}{c}145.457 . \\
718\end{array}$ & $\begin{array}{c}964.000 .6 \\
90\end{array}$ & $\begin{array}{c}15,08 \\
\%\end{array}$ \\
\hline 2017 & $\begin{array}{c}165.047 . \\
207\end{array}$ & $\begin{array}{c}1.076 .438 \\
.066\end{array}$ & $\begin{array}{c}15,33 \\
\%\end{array}$ \\
\hline 2018 & $\begin{array}{c}185.275 \\
331\end{array}$ & $\begin{array}{c}1.234 .200 \\
.039\end{array}$ & $\begin{array}{c}15,01 \\
\%\end{array}$ \\
\hline 2019 & $\begin{array}{c}203.665 \\
462\end{array}$ & $\begin{array}{c}1.343 .077 \\
.860\end{array}$ & $\begin{array}{c}15,16 \\
\%\end{array}$ \\
\hline 2020 & $\begin{array}{c}194.359 \\
102\end{array}$ & $\begin{array}{c}1.421 .785 \\
.007\end{array}$ & $\begin{array}{c}13,67 \\
\%\end{array}$ \\
\hline Min & $\begin{array}{c}49.820 .3 \\
29\end{array}$ & $\begin{array}{c}469.899 .2 \\
84\end{array}$ & $\begin{array}{c}10,60 \\
\%\end{array}$ \\
\hline $\begin{array}{c}\text { Mea } \\
\text { n }\end{array}$ & $\begin{array}{c}129.694 . \\
962\end{array}$ & $\begin{array}{c}929.115 .2 \\
44\end{array}$ & $\begin{array}{c}13,53 \\
\%\end{array}$ \\
\hline Max & $\begin{array}{c}203.665 \\
462\end{array}$ & $\begin{array}{c}1.421 .785 \\
.007\end{array}$ & $\begin{array}{c}15,33 \\
\%\end{array}$ \\
\hline
\end{tabular}

Seperti terlihat dari tabel di atas, nilai (maksimum) indeks level tertinggi perusahaan pada tahun 2017 adalah $15,33 \%$. Artinya di antara semua aset yang dimiliki perusahaan, perusahaan dapat menggunakan asetnya dengan benar. Nilai minimum koefisien primer $(\mathrm{min})$ muncul pada tahun 2011 dan sesuai dengan $10,60 \%$. Rata-rata rasio primer perusahaan adalah $13,53 \%$, hal ini menunjukan bahwa nilai pada penurunan aset dapat ditutupi oleh nilai capital equity sehingga nilai permodalan dapat memadai.

\section{b. Secondary Risk Ratio \\ Equity Capital x 100\% \\ Secondary risk assets}

Perhitungan SRR BRI

Tahun 2011-2020

\begin{tabular}{|c|c|c|c|}
\hline $\begin{array}{c}\text { Tah } \\
\text { un }\end{array}$ & $\begin{array}{l}\text { Equity } \\
\text { Capital }\end{array}$ & $\begin{array}{c}\text { Secondar } \\
\text { y Risk } \\
\text { Assets }\end{array}$ & $\begin{array}{c}\text { Second } \\
\text { ary } \\
\text { Risk } \\
\text { Ratio }\end{array}$ \\
\hline 201 & 49.820. & 481.183 .1 & 0,35 \\
\hline 1 & 329 & 33 & $\%$ \\
\hline 201 & 64.881. & 564.517 .4 & 11,49 \\
\hline 2 & 779 & 37 & $\%$ \\
\hline 201 & 78.869. & 21.311 .2 & 12,69 \\
\hline 3 & 916 & 62 & $\%$ \\
\hline 201 & & 797.431 .8 & 12,18 \\
\hline 4 & 986 & 87 & $\%$ \\
\hline 201 & 112.391 & 871.865 .2 & 12,89 \\
\hline 5 & .798 & 32 & $\%$ \\
\hline 201 & 145.457 & & 14,44 \\
\hline 6 & .718 & .266 & $\%$ \\
\hline 201 & 165.047 & 1.126 .339 & 14,65 \\
\hline 7 & .207 & .615 & $\%$ \\
\hline 201 & 185.275 & 1.289 .885 & 14,36 \\
\hline 8 & .331 & .905 & $\%$ \\
\hline 201 & 203.665 & 1.399 .369 & 14,55 \\
\hline 9 & .462 & .075 & $\%$ \\
\hline 202 & 194.359 & 1.487 .179 & 13,06 \\
\hline 0 & .102 & .532 & $\%$ \\
\hline Min & $\begin{array}{c}49.820 . \\
329\end{array}$ & $\begin{array}{c}481.183 .1 \\
33\end{array}$ & $\begin{array}{c}10,35 \\
\%\end{array}$ \\
\hline $\begin{array}{c}\text { Mea } \\
\text { n }\end{array}$ & $\begin{array}{c}129.694 \\
.962\end{array}$ & $\begin{array}{c}964.630 .3 \\
44\end{array}$ & $\begin{array}{c}13,06 \\
\%\end{array}$ \\
\hline Max & $\begin{array}{c}203.665 \\
.462\end{array}$ & $\begin{array}{c}1.487 .179 \\
.532\end{array}$ & $\begin{array}{c}14,65 \\
\%\end{array}$ \\
\hline
\end{tabular}


Dapat disimpulkan dari tabel di atas bahwa indeks risiko sekunder tertinggi (terbesar) perusahaan adalah $14,65 \%$ pada tahun 2017. Nilai (minimum value) indeks risiko sekunder terendah pada tahun 2011 sebesar 10,35\%. Nilai Secondary Risk Ratio pada rata-rata (mean) perusahaan adalah sebesar $13,06 \%$, hal ini menunjukan bahwa Secondary Risk Ratio pada PT Bank Rakyat Indonesia Tbk dapat menjaga kestabilan nilai asetnya dengan baik.

c. DAR

DAR $=$ Total Utang $\times 100 \%$ Aktiva

Perhitungan DAR BRI Tahun 2011-2020

\begin{tabular}{|c|c|c|c|}
\hline $\begin{array}{c}\text { Tah } \\
\text { un }\end{array}$ & $\begin{array}{c}\text { Total } \\
\text { Utang }\end{array}$ & Aktiva & DAR \\
\hline 2011 & $\begin{array}{c}420.078 .9 \\
55\end{array}$ & $\begin{array}{c}469.899 .2 \\
84\end{array}$ & $\begin{array}{c}89,39 \\
\%\end{array}$ \\
\hline 2012 & $\begin{array}{c}486.455 .0 \\
11\end{array}$ & $\begin{array}{c}551.336 .7 \\
90\end{array}$ & $\begin{array}{c}88,23 \\
\%\end{array}$ \\
\hline 2013 & $\begin{array}{c}527.500 .3 \\
26\end{array}$ & $\begin{array}{c}606.370 .2 \\
42\end{array}$ & $\begin{array}{c}86,99 \\
\%\end{array}$ \\
\hline 2014 & $\begin{array}{c}680.865 .0 \\
\end{array}$ & $\begin{array}{c}778.046 .0 \\
89\end{array}$ & $\begin{array}{c}87,50 \\
\%\end{array}$ \\
\hline 2015 & 733.606 .5 & 845.998 .3 & 86,71 \\
& 81 & 79 & $\%$ \\
\hline 2016 & $\begin{array}{c}818.542 .9 \\
72\end{array}$ & $\begin{array}{c}964.000 .6 \\
90\end{array}$ & $\begin{array}{c}84,91 \\
\%\end{array}$ \\
\hline 2017 & 911.390 .8 & 1.076 .438 & 84,66 \\
& 59 & .066 & $\%$ \\
\hline 2018 & 1.090 .664 & 1.234 .200 & 88,37 \\
& .084 & .039 & $\%$ \\
\hline 2019 & 1.139 .412 & 1.343 .077 & 84,83 \\
& .398 & .860 & $\%$ \\
\hline 2020 & 1.227 .425 & 1.421 .785 & 86,32 \\
& .905 & .007 & $\%$ \\
\hline
\end{tabular}

\begin{tabular}{|c|c|c|c|}
\hline Min & $\begin{array}{c}420.078 .9 \\
55\end{array}$ & $\begin{array}{c}469.899 .2 \\
84\end{array}$ & $\begin{array}{c}\mathbf{8 4 , 0 9} \\
\%\end{array}$ \\
\hline $\begin{array}{c}\text { Mea } \\
\text { n }\end{array}$ & $\begin{array}{c}\mathbf{8 0 3 . 5 9 4 . 2} \\
19\end{array}$ & $\begin{array}{c}\mathbf{9 2 9 . 1 1 5 . 2} \\
\mathbf{4 4}\end{array}$ & $\begin{array}{c}\mathbf{8 6 , 7 9} \\
\%\end{array}$ \\
\hline Max & $\begin{array}{c}1.227 .425 \\
.905\end{array}$ & $\begin{array}{c}\mathbf{1 . 4 2 1 . 7 8 5} \\
.007\end{array}$ & $\begin{array}{c}\mathbf{8 9 , 3 9} \\
\%\end{array}$ \\
\hline
\end{tabular}

Berdasarkan tabel di atas, dapat disimpulkan bahwa nilai debt to total assets ratio (max) perusahaan tertinggi terjadi pada tahun 2011 yaitu sebesar 89,39\%. Artinya perusahaan memiliki aset yang sangat tinggi dan perusahaan dapat memanfaatkan asetnya dengan baik. Terendah (terendah) adalah 2017-84,66\%. Nilai Debt to Total Assets Ratio pada rata-rata (mean) perusahaan adalah sebesar $86,79 \%$, hal ini menunjukan bahwa Debt to Total Assets Ratio pada PT Bank Rakyat Indonesia Tbk dapat menjaga kestabilan nilai aktivanya dengan baik

d. CAR

Jumlah Modal x 100\% ATMR

Perhitungan CAR BRI Tahun 2011-2020

\begin{tabular}{|c|c|c|c|}
\hline $\begin{array}{c}\text { Tah } \\
\text { un }\end{array}$ & $\begin{array}{c}\text { Jumlah } \\
\text { Modal }\end{array}$ & ATMR & CAR \\
\hline 2011 & $\begin{array}{c}41.315 .5 \\
85\end{array}$ & $\begin{array}{c}275.602 . \\
642\end{array}$ & $\begin{array}{c}14,96 \\
\%\end{array}$ \\
\hline 2012 & $\begin{array}{c}55.133 .6 \\
77\end{array}$ & $\begin{array}{c}325.352 . \\
028\end{array}$ & $\begin{array}{c}16,95 \\
\%\end{array}$ \\
\hline 2013 & $\begin{array}{c}69.472 .0 \\
36\end{array}$ & $\begin{array}{c}408.858 . \\
393\end{array}$ & $\begin{array}{c}16,99 \\
\%\end{array}$ \\
\hline 2014 & $\begin{array}{c}85.706 .5 \\
57\end{array}$ & $\begin{array}{c}468.182 . \\
076\end{array}$ & $\begin{array}{c}18,31 \\
\%\end{array}$ \\
\hline 2015 & $\begin{array}{c}110.580 . \\
617\end{array}$ & $\begin{array}{c}537.074 . \\
938\end{array}$ & $\begin{array}{c}20,59 \\
\%\end{array}$ \\
\hline 2016 & 142.910. & 623.857. & 22,91 \\
& 432 & 728 & $\%$ \\
\hline
\end{tabular}




\begin{tabular}{|c|c|c|c|}
\hline 2017 & $\begin{array}{c}161.751 . \\
939\end{array}$ & $\begin{array}{c}704.515 . \\
985\end{array}$ & $\begin{array}{c}22,96 \\
\%\end{array}$ \\
\hline 2018 & $\begin{array}{c}173.618 . \\
421\end{array}$ & $\begin{array}{c}818.608 . \\
240\end{array}$ & $\begin{array}{c}21,21 \\
\%\end{array}$ \\
\hline 2019 & $\begin{array}{c}195.986 . \\
650\end{array}$ & $\begin{array}{c}869.020 . \\
388\end{array}$ & $\begin{array}{c}22,55 \\
\%\end{array}$ \\
\hline 2020 & $\begin{array}{c}183.337 . \\
537\end{array}$ & $\begin{array}{c}889.596 . \\
695\end{array}$ & $\begin{array}{c}20,61 \\
\%\end{array}$ \\
\hline Min & $\begin{array}{c}\mathbf{4 1 . 3 1 5 . 5} \\
\mathbf{8 5}\end{array}$ & $\begin{array}{c}\mathbf{2 7 5 . 6 0 2} . \\
\mathbf{6 4 2}\end{array}$ & $\begin{array}{c}\mathbf{1 4 , 9 6} \\
\mathbf{\%}\end{array}$ \\
\hline $\begin{array}{c}\text { Mea } \\
\text { n }\end{array}$ & $\begin{array}{c}\mathbf{1 2 1 . 9 8 1} \\
\mathbf{3 4 5}\end{array}$ & $\begin{array}{c}\mathbf{6 7 8 . 7 9 9} . \\
\mathbf{4 8 7}\end{array}$ & $\begin{array}{c}\mathbf{1 9 , 8 0} \\
\mathbf{\%}\end{array}$ \\
\hline Max & $\begin{array}{c}\mathbf{1 9 5 . 9 8 6} . \\
\mathbf{6 5 0}\end{array}$ & $\begin{array}{c}\mathbf{8 8 9 . 5 9 6} . \\
\mathbf{6 9 5}\end{array}$ & $\begin{array}{c}\mathbf{2 2 , 9 6} \\
\mathbf{\%}\end{array}$ \\
& & & \multicolumn{2}{|c}{} \\
\end{tabular}

Terlihat dari tabel di atas, indeks kecukupan modal (max) tertinggi perusahaan muncul pada tahun 2017 yaitu sebesar 22,96\%. Artinya jumlah modal yang dimiliki perusahaan tinggi, sehingga perusahaan dapat menggunakannya. Pada tahun 2011, rasio ekuitas terendah (min) dicapai sebesar 14,96\%. Hal ini dikarenakan masyarakat belum sepenuhnya memanfaatkan modalnya. Nilai rata-rata (mean value) rasio ekuitas perusahaan adalah 19,80\%, hal ini menunjukan bahwa Capital Adequancy Ratio pada PT Bank Rakyat Indonesia Tbk dapat menjaga kecukupan jumlah modalnya dengan baik sehingga dapat meminimalisir resiko kerugian, sehingga keberlangsungan operasional perusahaan dapat berjalan dengan baik dan lancar untuk dapat terus mencapai tujuan perusahaan

\section{Rasio Profitabilitas}

\section{a. ROA}

Laba Bersih Sebelum Pajak x 100\% Aktiva

Perhitungan ROA BRI
Tahun 2011-2020

\begin{tabular}{|c|c|c|c|}
\hline $\begin{array}{c}\text { Tah } \\
\text { un }\end{array}$ & $\begin{array}{c}\text { Laba } \\
\text { Bersih } \\
\text { Sebelu } \\
\text { m } \\
\text { Pajak }\end{array}$ & Aktiva & $\begin{array}{c}\text { RO } \\
\text { A }\end{array}$ \\
\hline 2011 & $\begin{array}{c}18.755 .8 \\
80\end{array}$ & $\begin{array}{c}469.899 .28 \\
4\end{array}$ & $\begin{array}{c}3,99 \\
\%\end{array}$ \\
\hline 2012 & $\begin{array}{c}23.859 .5 \\
72\end{array}$ & $\begin{array}{c}551.336 .79 \\
0\end{array}$ & $\begin{array}{c}4,32 \\
\%\end{array}$ \\
\hline 2013 & $\begin{array}{c}27.647 .8 \\
76\end{array}$ & $\begin{array}{c}606.370 .24 \\
2\end{array}$ & $\begin{array}{c}4,55 \\
\%\end{array}$ \\
\hline 2014 & $\begin{array}{c}30.723 .7 \\
12\end{array}$ & $\begin{array}{c}778.046 .08 \\
5\end{array}$ & $\begin{array}{c}3,94 \\
\%\end{array}$ \\
\hline 2015 & $\begin{array}{c}32.211 .4 \\
38\end{array}$ & $\begin{array}{c}845.998 .37 \\
9\end{array}$ & $\begin{array}{c}3,80 \\
\%\end{array}$ \\
\hline 2016 & $\begin{array}{c}33.441 .6 \\
43\end{array}$ & $\begin{array}{c}964.000 .69 \\
0\end{array}$ & $\begin{array}{c}3,46 \\
\%\end{array}$ \\
\hline 2017 & $\begin{array}{c}36.350 .7 \\
30\end{array}$ & $\begin{array}{c}1.076 .438 \\
066\end{array}$ & $\begin{array}{c}3,37 \\
\%\end{array}$ \\
\hline 2018 & $\begin{array}{c}40.798 .0 \\
64\end{array}$ & $\begin{array}{c}1.234 .200 \\
039\end{array}$ & $\begin{array}{c}3,30 \\
\%\end{array}$ \\
\hline 2019 & $\begin{array}{c}42.949 .8 \\
92\end{array}$ & $\begin{array}{c}1.343 .077 \\
860\end{array}$ & $\begin{array}{c}3,19 \\
\%\end{array}$ \\
\hline 2020 & $\begin{array}{c}26.161 .1 \\
11\end{array}$ & $\begin{array}{c}1.421 .785 \\
007\end{array}$ & $\begin{array}{c}1,84 \\
\%\end{array}$ \\
\hline Min & $\begin{array}{c}18.755 .8 \\
80\end{array}$ & $\begin{array}{c}469.899 .28 \\
4\end{array}$ & $\begin{array}{c}1,84 \\
\%\end{array}$ \\
\hline $\begin{array}{c}\text { Mea } \\
\text { n }\end{array}$ & $\begin{array}{c}31.289 .9 \\
91\end{array}$ & $\begin{array}{c}929.115 .24 \\
4\end{array}$ & $\begin{array}{c}3,57 \\
\%\end{array}$ \\
\hline Max & $\begin{array}{c}42.949 .8 \\
92\end{array}$ & $\begin{array}{c}1.421 .785 \\
007\end{array}$ & $\begin{array}{c}\mathbf{4 , 5 5} \\
\%\end{array}$ \\
\hline
\end{tabular}

Seperti dapat dilihat dari tabel di atas, ROA tertinggi perusahaan dicapai pada tahun 2013, sebesar 4,55\%. Tingginya nilai Retun On Assets pada tahun 2013 disebabkan karena total aset terhadap laba bersih 
meningkat hal tersebut membuat naiknya nilai Retun On Assets . Nilai Retun On Assets terendah ( $\mathrm{min}$ ) perusahaan terjadi pada tahun 2020 yaitu sebesar $1,84 \%$.. Nilai Retun On Assets rata-rata (mean) perusahaan adalah sebesar $3,57 \%$. Hal ini menunjukan bahwa PT Bank Rakyat Indonesia Tbk bisa menghasilkan laba yang maksimal setiap periode dan memiliki kinerja yang kurang maksmimal karena belum bisa menghasilkan labanya dengan maksimal.

b. ROE

Laba Bersih Setelah Pajak x 100\% Ekuitas

Perhitungan ROE BRI

Tahun 2011-2020

\begin{tabular}{|c|c|c|c|}
\hline $\begin{array}{c}\text { Tahu } \\
\text { n }\end{array}$ & $\begin{array}{c}\text { Laba } \\
\text { Bersih } \\
\text { Setelah } \\
\text { Pajak }\end{array}$ & Ekuitas & ROE \\
\hline 2011 & $\begin{array}{c}15.087 .9 \\
96\end{array}$ & $\begin{array}{c}49.820 .32 \\
9\end{array}$ & $\begin{array}{c}30,28 \\
\%\end{array}$ \\
\hline 2012 & $\begin{array}{c}18.687 .3 \\
80\end{array}$ & $\begin{array}{c}64.881 .77 \\
9\end{array}$ & $\begin{array}{c}28,80 \\
\%\end{array}$ \\
\hline 2013 & $\begin{array}{c}21.160 .1 \\
50\end{array}$ & $\begin{array}{c}78.869 .91 \\
6\end{array}$ & $\begin{array}{c}26,82 \\
\%\end{array}$ \\
\hline 2014 & $\begin{array}{c}24.176 .3 \\
58\end{array}$ & $\begin{array}{c}97.180 .98 \\
6\end{array}$ & $\begin{array}{c}24,87 \\
\%\end{array}$ \\
\hline 2015 & $\begin{array}{c}25.204 .1 \\
50\end{array}$ & $\begin{array}{c}112.391 .7 \\
98\end{array}$ & $\begin{array}{c}22,42 \\
\%\end{array}$ \\
\hline 2016 & 25.753 .4 & 145.457 .7 & 17,70 \\
& 56 & 18 & $\%$ \\
\hline 2017 & 28.469 .2 & 165.047 .2 & 17,24 \\
& 35 & 07 & $\%$ \\
\hline 2018 & 32.418 .4 & 185.275 .3 & 17,49 \\
& 86 & 31 & $\%$ \\
\hline 2019 & 34.028 .6 & 203.665 .4 & 16,70 \\
\hline
\end{tabular}

\begin{tabular}{|c|c|c|c|}
\hline & 85 & 62 & $\%$ \\
\hline 2020 & $\begin{array}{c}18.353 .3 \\
03\end{array}$ & $\begin{array}{c}194.359 .1 \\
02\end{array}$ & $9,44 \%$ \\
\hline Min & $\begin{array}{c}\mathbf{1 5 . 0 8 7 . 9} \\
\mathbf{9 6}\end{array}$ & $\begin{array}{c}\mathbf{4 9 . 8 2 0 . 3 2} \\
\mathbf{9}\end{array}$ & $\begin{array}{c}\mathbf{9 , 4 4} \\
\text { \% }\end{array}$ \\
\hline $\begin{array}{c}\text { Mea } \\
\text { n }\end{array}$ & $\begin{array}{c}\mathbf{2 4 . 3 3 3 . 9} \\
\mathbf{1 9}\end{array}$ & $\begin{array}{c}\mathbf{1 2 9 . 6 9 4 . 9} \\
\mathbf{6 2}\end{array}$ & $\begin{array}{c}\mathbf{2 1 , 1 7} \\
\mathbf{\%}\end{array}$ \\
\hline $\begin{array}{c}\text { Max } \\
\mathbf{3 4 . 0 2 8 . 6} \\
\mathbf{8 5}\end{array}$ & $\begin{array}{c}\mathbf{2 0 3 . 6 6 5 . 4} \\
\mathbf{6 2}\end{array}$ & $\begin{array}{c}\mathbf{3 0 , 2 8} \\
\mathbf{\%}\end{array}$ \\
\hline
\end{tabular}

Seperti terlihat dari tabel di atas, return on equity $(\max )$ tertinggi perusahaan dicapai pada tahun 2011 yaitu sebesar $30,28 \%$. Pengembalian ekuitas minimum (terendah) dari perusahaan pada tahun 2020 adalah $9,44 \%$. Rata-rata pengembalian modal perusahaan (rata-rata) adalah $21,17 \%$. pertunjukan, kinerja yang semakin baik akan berdampak baik untuk keberlangsungan perusahaan

\section{c. NIM}

Pendapatan Bunda x 100\%

Aktiva Produktif

Perhitungan NIM BRI Tahun 2011-2020

\begin{tabular}{|c|c|c|c|}
\hline $\begin{array}{c}\text { Tah } \\
\text { un }\end{array}$ & $\begin{array}{c}\text { Pendapa } \\
\text { tan } \\
\text { Bunga }\end{array}$ & $\begin{array}{c}\text { Aktiva } \\
\text { Produktif }\end{array}$ & $\begin{array}{c}\text { Net } \\
\text { Inter } \\
\text { est } \\
\text { Marg } \\
\text { in }\end{array}$ \\
\hline 2011 & $\begin{array}{c}34.427 .0 \\
76\end{array}$ & $\begin{array}{c}469.899 .2 \\
84\end{array}$ & $\begin{array}{c}7,32 \\
\%\end{array}$ \\
\hline 2012 & $\begin{array}{c}36.483 .7 \\
66\end{array}$ & $\begin{array}{c}551.336 .7 \\
90\end{array}$ & $\begin{array}{c}6,61 \\
\%\end{array}$ \\
\hline 2013 & 42.905 .9 & 606.370 .2 & 7,07 \\
& 05 & 42 & $\%$ \\
\hline 2014 & 50.119 .9 & 778.046 .0 & 6,44 \\
& 91 & 85 & $\%$ \\
\hline 2015 & 56.510 .8 & 845.998 .3 & 6,67 \\
& 74 & 79 & $\%$ \\
\hline
\end{tabular}




\begin{tabular}{|c|c|c|c|}
\hline 2016 & $\begin{array}{c}63.095 .0 \\
70\end{array}$ & $\begin{array}{c}964.000 .6 \\
90\end{array}$ & $\begin{array}{c}6,55 \\
\%\end{array}$ \\
\hline 2017 & $\begin{array}{c}70.428 .5 \\
46\end{array}$ & $\begin{array}{c}1.076 .438 . \\
066\end{array}$ & $\begin{array}{c}6,54 \\
\%\end{array}$ \\
\hline 2018 & $\begin{array}{c}77.665 .7 \\
72\end{array}$ & $\begin{array}{c}1.234 .200 . \\
039\end{array}$ & $\begin{array}{c}6,29 \\
\%\end{array}$ \\
\hline 2019 & $\begin{array}{c}78.560 .3 \\
03\end{array}$ & $\begin{array}{c}1.343 .077 . \\
860\end{array}$ & $\begin{array}{c}5,84 \\
\%\end{array}$ \\
\hline 2020 & $\begin{array}{c}75.146 .9 \\
98\end{array}$ & $\begin{array}{c}1.421 .785 \\
007\end{array}$ & $\begin{array}{c}5,28 \\
\%\end{array}$ \\
\hline Min & $\begin{array}{c}\mathbf{3 4 . 4 2 7 . 0} \\
\mathbf{7 6}\end{array}$ & $\begin{array}{c}\mathbf{4 6 9 . 8 9 9 . 2} \\
\mathbf{8 4}\end{array}$ & $\begin{array}{c}\mathbf{5 , 2 8} \\
\mathbf{\%}\end{array}$ \\
\hline $\begin{array}{c}\text { Mea } \\
\text { n }\end{array}$ & $\begin{array}{c}\mathbf{5 8 . 5 3 4 . 4} \\
\mathbf{3 0}\end{array}$ & $\begin{array}{c}\mathbf{9 2 9 . 1 1 5 . 2} \\
\mathbf{4 4}\end{array}$ & $\begin{array}{c}\mathbf{6 , 4 6} \\
\mathbf{\%}\end{array}$ \\
\hline $\begin{array}{c}\text { Max } \\
\mathbf{7 8 . 5 6 0 . 3}\end{array}$ & $\mathbf{1 . 4 2 1 . 7 8 5}$ & $\mathbf{7 , 3 2}$ \\
$\mathbf{0 3}$ & $\mathbf{0 0 7}$ & $\mathbf{\%}$ \\
\hline
\end{tabular}

Bedasarkan tabel diatas dapat disimpulkan bahwa nilai Net Interest Margin tertinggi ( $\max$ ) perusahaan terjadi pada tahun 2011 yaitu sebesar 7,32\%. Nilai Net Interest Margin terendah ( $\mathrm{min}$ ) terjadi pada tahun 2020 yaitu sebesar 5,28\%. Nilai Net Interest Margin pada rata-rata (mean) perusahaan adalah sebesar 6,46\%, hal ini menunjukan bahwa Net Interest Margin pada PT Bank Rakyat Indonesia Tbk dapat menjaga aktivanya dengan baik

d. BOPO

Biaya Operasional x 100\%

Pendapatan Operasional

Perhitungan BOPO BRI

Tahun 2011-2020

\begin{tabular}{|l|c|c|c|}
\hline $\begin{array}{l}\text { Tah } \\
\text { un }\end{array}$ & $\begin{array}{c}\text { Biaya } \\
\text { Operasio } \\
\text { nal }\end{array}$ & $\begin{array}{c}\text { Pendapa } \\
\text { tan } \\
\text { Operasio } \\
\text { nal }\end{array}$ & $\begin{array}{c}\text { BOP } \\
\text { O }\end{array}$ \\
\hline 2011 & $\begin{array}{c}40.203 .0 \\
51\end{array}$ & $\begin{array}{c}51.512 .7 \\
03\end{array}$ & $\begin{array}{c}78,04 \\
\%\end{array}$ \\
\hline
\end{tabular}

\begin{tabular}{|c|c|c|c|}
\hline 2012 & $\begin{array}{c}44.873 .4 \\
98\end{array}$ & $\begin{array}{c}55.974 .7 \\
98\end{array}$ & $\begin{array}{c}80,16 \\
\%\end{array}$ \\
\hline 2013 & $\begin{array}{c}51.071 .0 \\
77\end{array}$ & $\begin{array}{c}64.189 .4 \\
72\end{array}$ & $\begin{array}{c}79,56 \\
\%\end{array}$ \\
\hline 2014 & $\begin{array}{c}59.297 .8 \\
64\end{array}$ & $\begin{array}{c}75.578 .2 \\
98\end{array}$ & $\begin{array}{c}78,45 \\
\%\end{array}$ \\
\hline 2015 & $\begin{array}{c}70.181 .0 \\
72\end{array}$ & $\begin{array}{c}86.399 .6 \\
93\end{array}$ & $\begin{array}{c}81,22 \\
\%\end{array}$ \\
\hline 2016 & $\begin{array}{c}79.774 .2 \\
80\end{array}$ & $\begin{array}{c}96.123 .1 \\
43\end{array}$ & $\begin{array}{c}82,99 \\
\%\end{array}$ \\
\hline 2017 & $\begin{array}{c}89.121 .3 \\
82\end{array}$ & $\begin{array}{c}106.741 . \\
145\end{array}$ & $\begin{array}{c}83,49 \\
\%\end{array}$ \\
\hline 2018 & 101.091. & 119.656. & 84,48 \\
& 202 & 056 & $\%$ \\
\hline 2019 & 106.111. & 120.342. & 88,17 \\
& 939 & 778 & $\%$ \\
\hline 2020 & 103.577. & 121.543. & 85,21 \\
& 131 & 256 & $\%$ \\
\hline Min & $\mathbf{4 0 . 2 0 3 . 0}$ & $\mathbf{5 1 . 5 1 2 . 7}$ & $\mathbf{7 8 , 0 4}$ \\
& $\mathbf{5 1}$ & $\mathbf{0 3}$ & $\mathbf{\%}$ \\
\hline Mea & $\mathbf{7 4 . 5 3 2 . 9}$ & $\mathbf{8 9 . 8 0 6 . 1}$ & $\mathbf{8 2 , 1 7}$ \\
$\mathbf{4 9}$ & $\mathbf{4 9}$ & $\mathbf{9 3}$ \\
\hline Max & $\mathbf{1 0 6 . 1 1 1 .}$ & $\mathbf{1 2 1 . 5 4 3 .}$ & $\mathbf{8 8 , 1 7}$ \\
& $\mathbf{9 3 9}$ & $\mathbf{2 5 6}$ \\
\hline & & & \\
\hline
\end{tabular}

Bedasarkan tabel diatas dapat disimpulkan bahwa nilai BOPO tertinggi (max) perusahaan terjadi pada tahun 2019 yaitu sebesar 88,17\%. Hal ini berarti pendapatan operasional yang dimiliki perusahaan tinggi maka perusahaan mampu memanfaatkan pendapatan operasionalnya dengan baik. Nilai BOPO terendah ( $\mathrm{min}$ ) terjadi pada tahun 2011 yaitu sebesar 78,04\%. Nilai BOPO pada rata-rata (mean) perusahaan adalah sebesar $82,17 \%$, hal ini menunjukan bahwa BOPO pada PT Bank Rakyat Indonesia Tbk belum dapat menjaga pendapatan operasionalnya dengan baik, dan baiaya 
operasional yang terus meningkat disetiap tahunnya, sehingga keberlangsungan operasional perusahaan kurang berjalan dengan baik

4. Hasil Analisa

Berdasarkan analisis data, kinerja keuangan masing-masing indeks dapat diukur menurut persentase standar industri berikut.:

Hasil Analisa Tingkat Kinerja Keuangan

Pada Rasio Likuiditas Solvabilitas dan Profitabilitas BRI Tahun 2011-2012

\begin{tabular}{|c|c|c|c|c|}
\hline Keteran & \multicolumn{4}{|c|}{ Rasio Likuiditas } \\
\hline Tahun & $\begin{array}{c}\text { Curre } \\
\text { nt } \\
\text { Ratio }\end{array}$ & $\begin{array}{l}\text { Cash } \\
\text { Ratio }\end{array}$ & $\begin{array}{c}\text { Loan } \\
\text { to } \\
\text { Depos } \\
\text { it } \\
\text { Ratio }\end{array}$ & $\begin{array}{c}\text { Loan } \\
\text { to } \\
\text { Assets } \\
\text { Ratio }\end{array}$ \\
\hline 2011 & $\begin{array}{c}74,23 \\
\%\end{array}$ & $\begin{array}{c}11,33 \\
\%\end{array}$ & $\begin{array}{c}74,27 \\
\%\end{array}$ & $\begin{array}{c}81,77 \\
\%\end{array}$ \\
\hline 2012 & $\begin{array}{c}77,91 \\
\%\end{array}$ & $\begin{array}{c}12,53 \\
\%\end{array}$ & $\begin{array}{c}77,91 \\
\%\end{array}$ & $\begin{array}{c}81,64 \\
\%\end{array}$ \\
\hline 2013 & $\begin{array}{c}88,53 \\
\%\end{array}$ & $\begin{array}{c}12,11 \\
\%\end{array}$ & $\begin{array}{c}85,39 \\
\%\end{array}$ & $\begin{array}{c}80,20 \\
\%\end{array}$ \\
\hline 2014 & $\begin{array}{c}86,67 \\
\%\end{array}$ & $\begin{array}{c}12,01 \\
\%\end{array}$ & $\begin{array}{c}81,67 \\
\%\end{array}$ & $\begin{array}{c}77,16 \\
\%\end{array}$ \\
\hline 2015 & $\begin{array}{c}86,87 \\
\%\end{array}$ & $\begin{array}{c}13,78 \\
\%\end{array}$ & $\begin{array}{c}86,87 \\
\%\end{array}$ & $\begin{array}{c}75,97 \\
\%\end{array}$ \\
\hline 2016 & $\begin{array}{c}87,76 \\
\%\end{array}$ & $\begin{array}{c}10,81 \\
\%\end{array}$ & $\begin{array}{c}87,76 \\
\%\end{array}$ & $\begin{array}{c}75,08 \\
\%\end{array}$ \\
\hline 2017 & $\begin{array}{c}88,13 \\
\%\end{array}$ & $9,96 \%$ & $\begin{array}{c}88,13 \\
\%\end{array}$ & $\begin{array}{c}74,62 \\
\%\end{array}$ \\
\hline 2018 & $\begin{array}{c}88,95 \\
\%\end{array}$ & $\begin{array}{c}10,66 \\
\%\end{array}$ & $\begin{array}{c}88,95 \\
\%\end{array}$ & $\begin{array}{c}72,76 \\
\%\end{array}$ \\
\hline 2019 & $\begin{array}{c}88,63 \\
\%\end{array}$ & $\begin{array}{c}10,18 \\
\%\end{array}$ & $\begin{array}{c}88,63 \\
\%\end{array}$ & $\begin{array}{c}72,20 \\
\%\end{array}$ \\
\hline 2020 & $\begin{array}{c}83,66 \\
\%\end{array}$ & $7,66 \%$ & $\begin{array}{c}83,66 \\
\%\end{array}$ & $\begin{array}{c}74,03 \\
\%\end{array}$ \\
\hline Rata- & 86,42 & 11,10 & 84,63 & 76,54 \\
\hline
\end{tabular}

\begin{tabular}{|c|c|c|c|c|}
\hline rata & $\%$ & $\%$ & $\%$ & $\%$ \\
\hline $\begin{array}{c}\text { Standar } \\
\text { Bank } \\
\begin{array}{c}\text { Indones } \\
\text { ia }\end{array}\end{array}$ & $\begin{array}{c}>\mathbf{8 3 , 1} \\
\mathbf{1 \%}\end{array}$ & $\begin{array}{c}>\mathbf{1 0 , 4} \\
\mathbf{3 \%}\end{array}$ & $\begin{array}{c}<\mathbf{8 4 , 8} \\
\mathbf{7 \%}\end{array}$ & $\begin{array}{c}>\mathbf{7 6 , 6} \\
\mathbf{0 \%}\end{array}$ \\
\hline $\begin{array}{c}\text { Penilaia } \\
\text { n }\end{array}$ & Sehat & Sehat & Sehat & $\begin{array}{c}\text { Kura } \\
\text { ng } \\
\text { Sehat }\end{array}$ \\
\hline
\end{tabular}

\begin{tabular}{c|c}
$\begin{array}{c}\text { Ketera } \\
\text { ngan }\end{array}$ & Rasio Solvabilitas \\
\hline
\end{tabular}

\begin{tabular}{|c|c|c|c|c|}
\hline Tahun & $\begin{array}{c}\text { Prima } \\
\text { ry } \\
\text { Ratio }\end{array}$ & $\begin{array}{l}\text { Secon } \\
\text { dary } \\
\text { Risk } \\
\\
\text { Ratio }\end{array}$ & $\begin{array}{c}\begin{array}{c}\text { Debt } \\
\text { to }\end{array} \\
\text { Assets } \\
\text { Ratio }\end{array}$ & $\begin{array}{c}\text { Capital } \\
\text { Adequ } \\
\text { ancy } \\
\text { Ratio }\end{array}$ \\
\hline 2011 & $\begin{array}{c}10,60 \\
\%\end{array}$ & $\begin{array}{c}10,35 \\
\%\end{array}$ & $\begin{array}{c}89,39 \\
\%\end{array}$ & $14,96 \%$ \\
\hline 2012 & $\begin{array}{c}11,76 \\
\%\end{array}$ & $\begin{array}{c}11,49 \\
\%\end{array}$ & $\begin{array}{c}88,23 \\
\%\end{array}$ & $16,95 \%$ \\
\hline 2013 & $\begin{array}{c}13,00 \\
\%\end{array}$ & $\begin{array}{c}12,69 \\
\%\end{array}$ & $\begin{array}{c}86,99 \\
\%\end{array}$ & $16,99 \%$ \\
\hline 2014 & $\begin{array}{c}12,49 \\
\%\end{array}$ & $\begin{array}{c}12,18 \\
\%\end{array}$ & $\begin{array}{c}87,50 \\
\%\end{array}$ & $18,31 \%$ \\
\hline 2015 & $\begin{array}{c}13,28 \\
\%\end{array}$ & $\begin{array}{c}12,89 \\
\%\end{array}$ & $\begin{array}{c}86,71 \\
\%\end{array}$ & $20,59 \%$ \\
\hline 2016 & $\begin{array}{c}15,08 \\
\%\end{array}$ & $\begin{array}{c}14,44 \\
\%\end{array}$ & $\begin{array}{c}84,91 \\
\%\end{array}$ & $22,91 \%$ \\
\hline 2017 & $\begin{array}{c}15,33 \\
\%\end{array}$ & $\begin{array}{c}14,65 \\
\%\end{array}$ & $\begin{array}{c}84,66 \\
\%\end{array}$ & $22,96 \%$ \\
\hline 2018 & $\begin{array}{c}14,28 \\
\%\end{array}$ & $\begin{array}{c}14,36 \\
\%\end{array}$ & $\begin{array}{c}84,09 \\
\%\end{array}$ & $21,21 \%$ \\
\hline 2019 & $\begin{array}{c}15,16 \\
\%\end{array}$ & $\begin{array}{c}14,55 \\
\%\end{array}$ & $\begin{array}{c}84,83 \\
\%\end{array}$ & $22,55 \%$ \\
\hline 2020 & $\begin{array}{c}13,67 \\
\%\end{array}$ & $\begin{array}{c}13,06 \\
\%\end{array}$ & $\begin{array}{c}86,32 \\
\%\end{array}$ & $20,61 \%$ \\
\hline
\end{tabular}




\begin{tabular}{|c|c|c|c|c|}
\hline $\begin{array}{c}\text { Rata- } \\
\text { rata }\end{array}$ & $\begin{array}{c}13,53 \\
\%\end{array}$ & $\begin{array}{c}13,06 \\
\%\end{array}$ & $\begin{array}{c}\mathbf{8 6 , 7 9} \\
\%\end{array}$ & $\begin{array}{c}19,80 \\
\%\end{array}$ \\
\hline $\begin{array}{c}\text { Standar } \\
\text { Industr } \\
\text { i }\end{array}$ & $\begin{array}{c}>13,5 \\
0 \%\end{array}$ & $\begin{array}{c}>13,50 \\
\%\end{array}$ & $\begin{array}{c}>85,3 \\
6 \%\end{array}$ & $\begin{array}{c}>17,16 \\
\%\end{array}$ \\
\hline $\begin{array}{c}\text { Penilaia } \\
\text { n }\end{array}$ & Sehat & $\begin{array}{c}\text { Kuran } \\
\text { g } \\
\text { Sehat }\end{array}$ & Sehat & Sehat \\
\hline
\end{tabular}

Sumber: ( data yang sudah diolah 2021)

\begin{tabular}{|c|c|c|c|c|}
\hline $\begin{array}{c}\text { Keteran } \\
\text { gan }\end{array}$ & \multicolumn{4}{|c|}{ Rasio Profitabilitas } \\
\hline Tahun & $\begin{array}{c}\text { Retur } \\
\text { n on }\end{array}$ & $\begin{array}{c}\text { Return } \\
\text { on } \\
\text { Asset } \\
\text { s }\end{array}$ & $\begin{array}{c}\text { Equity } \\
\text { Intere } \\
\text { st } \\
\text { Marg } \\
\text { in }\end{array}$ & \\
\hline 2011 & $\begin{array}{c}3,99 \\
\%\end{array}$ & $\begin{array}{c}30,28 \\
\%\end{array}$ & $\begin{array}{c}7,32 \\
\%\end{array}$ & $\begin{array}{c}78,04 \\
\%\end{array}$ \\
\hline 2012 & $\begin{array}{c}4,32 \\
\%\end{array}$ & $\begin{array}{c}28,80 \\
\%\end{array}$ & $\begin{array}{c}6,61 \\
\%\end{array}$ & $\begin{array}{c}80,16 \\
\%\end{array}$ \\
\hline 2013 & $\begin{array}{c}4,55 \\
\%\end{array}$ & $\begin{array}{c}26,82 \\
\%\end{array}$ & $\begin{array}{c}7,27 \\
\%\end{array}$ & $\begin{array}{c}79,56 \\
\%\end{array}$ \\
\hline 2014 & $\begin{array}{c}3,94 \\
\%\end{array}$ & $\begin{array}{c}24,87 \\
\%\end{array}$ & $\begin{array}{c}6,44 \\
\%\end{array}$ & $\begin{array}{c}78,45 \\
\%\end{array}$ \\
\hline 2015 & $\begin{array}{c}3,80 \\
\%\end{array}$ & $\begin{array}{c}22,42 \\
\%\end{array}$ & $\begin{array}{c}6,67 \\
\%\end{array}$ & $\begin{array}{c}81,22 \\
\%\end{array}$ \\
\hline 2016 & $\begin{array}{c}3,46 \\
\%\end{array}$ & $\begin{array}{c}17,70 \\
\%\end{array}$ & $\begin{array}{c}6,55 \\
\%\end{array}$ & $\begin{array}{c}82,99 \\
\%\end{array}$ \\
\hline 2017 & $\begin{array}{c}3,37 \\
\%\end{array}$ & $\begin{array}{c}17,24 \\
\%\end{array}$ & $\begin{array}{c}6,54 \\
\%\end{array}$ & $\begin{array}{c}83,49 \\
\%\end{array}$ \\
\hline$\%$ & $\begin{array}{c}3,30 \\
\%\end{array}$ & $\begin{array}{c}17,49 \\
\%\end{array}$ & $\begin{array}{c}5,77 \\
\%\end{array}$ \\
\hline 2018 \\
\end{tabular}

\begin{tabular}{|c|c|c|c|c|}
\hline $\begin{array}{c}\text { Rata- } \\
\text { rata }\end{array}$ & $\begin{array}{c}\mathbf{3 , 5 7} \\
\%\end{array}$ & $\begin{array}{c}\mathbf{2 1 , 1 7} \\
\%\end{array}$ & $\begin{array}{c}\mathbf{6 , 4 6} \\
\%\end{array}$ & $\begin{array}{c}\mathbf{8 2 , 1 7} \\
\%\end{array}$ \\
\hline $\begin{array}{c}\text { Standar } \\
\text { Industri }\end{array}$ & $\begin{array}{c}>\mathbf{2 , 9 6} \\
\%\end{array}$ & $\begin{array}{c}>18,10 \\
\%\end{array}$ & $\begin{array}{c}>\mathbf{5 , 8 5} \\
\%\end{array}$ & $\begin{array}{c}<\mathbf{7 3 , 9 0} \\
\%\end{array}$ \\
\hline $\begin{array}{c}\text { Penilaia } \\
\mathbf{n}\end{array}$ & Sehat & Sehat & Sehat & $\begin{array}{c}\text { Kuran } \\
\text { g } \\
\text { Sehat }\end{array}$ \\
\hline
\end{tabular}

Sumber: ( data yang sudah diolah 2021)

\section{KESIMPULAN\& SARAN}

\section{A. Kesimpulan}

beraasarkan analisis dan pembahasan penelitian ini "Analisis Rasio Likuiditas Rasio Solvabilitas dan Profitabilitas Dalam Mengukur Kinerja Keuangan PT Bank Rakyat Indonesia Tbk Periode 20112020". Kemudian peneliti dapat menarik kesimpulan sebagai berikut:

1. Rasio Likuiditas

Pada pengukuran Current ratio dengan total rata-rata $86,42 \%$ ,kinerja keuangan dinyatakan sehat karena melebihi standar industri bank, Sedangkan pada Cash ratio dengan total rata-rata $11,10 \%$ kinerja keuangan bank dinyatakan sehat karena melebihi dari standar yang ditetapkan, pada LDR dengan total rata-rata $84,63 \%$ maka kinerja keuangan dinyatakan sehat karena tidak melebihi standar industri bank sedangkan pada rasio LAR sedang rata-rata $76,54 \%$ dinyatakan kurang sehat karana kurang darai stndar industri

2. Rasio Solvabilitas

Pada penggukuran Primary Ratio dengan rata-rata $13,53 \%$ maka kinerja keuangan dinyatakan sehat karena melebihi standar yang ditetapkan, sedangkan pada rasio Secondary risk ratio dengan rata-rata $13,06 \%$ dinyatakan kurang sehat karena kurang dari standar yang ditetapkan, sedangkan pada DAR dengan rata-rata $86,79 \%$ maka 
kinerja keuangan dinyatakan sehat karena melebihi standar industri yang ditetapkan dan pada rasio CAR dengan total rata-rata $21,78 \%$ dinyatakan sehat karena melebihi stndar industri yang telah ditetapkan.

3. Rasio Profitabilitas

Pada pengukuran ROA dengan total rata-rata $3,57 \%$ maka kinerja keuangan dinyatakan sehat karena melebihi standar industri yang ditetapkan, sedangkan pada rasio ROE dengan total rata-rata $21,17 \%$ maka kinerja keuangan dinyatakan sehat karena melebihi standar yang ditetapkan, pada rasio Net Interest Margin dengan total rata-rata 6,46\% maka kinerja keuangan dinyatakan sehat karena melebihi stndar yaang ditetapkan sedangkan pada nilai BOPO dengan total rata-rata $82,17 \%$ dinyakan kurang sehat melebihi stndar kentutan yang telah ditetapkan.

\section{B. Saran}

Untuk Perusahaan PT Bank Rakyat Indonesia Tbk agar tetap terus menjaga kestabilan dan meningkatkan kinerja keuangan perusahaan agar terus bisa bersaing maraknya persaingan yang ada.

Dan agar keberlangsungan operasional perusahaan akan terus berjalan dengan lancar kedepannya

\section{Bagi Peneliti selanjutnya}

Bagi peneliti selanjtnya diharapkan agar dapat meneliti menggunakan variabel-varibel yang lain agar dapat terus berkembang peneletian ini dengan jauh lebih baik.

\section{DAFTAR PUSTAKA}

Dwi, P., \& Rifka, J. (2012). Analisis Laporan Keuangan Konsep dan Aplikasi. Yogyakarta: YKPN.

Fahmi, I. (2013). Analisis Laporan Keuangan. Bandung: Alfabeta.

Fahmi, I. (2015). Analisis Laporan Keuangan.
Bandung: Alfabeta..

Kamaludin. (2011). Manajemen Keuangan. Bandung: Bandar Maju.

Kasmir. (2012). Analisis Laporan Keuangan. Jakarta: Raja Grafindo Persada.

Kasmir. (2014). Analisis Laporan Keuangan. Jakarta: Rajawali Pers.

Kasmir. (2015). Pengantar Manajemen Keuangan. Jakarta: Raja Grafindo Persada.

Kasmir. (2020). Analisis Laporan Keuangan. Jakarta: Raja Grafindo Persada.

Mulyadi. (2014). Akutansi Biaya. Yohyakarta: Universitas Gajah Mada.

Munawir. (2010). Analisis Laporan Keuangan. Yogyakarta: Liberty Yogyakarta.

Munawir. (2016). Analisis Laporan Keuangan. Yogyakarta: Liberty Yogyakarta.

Purnomo, S., \& Pasaribu, V. L. D. (2019). Pergerakan Harga Saham Pt Adaro Energy Tbk (Adro) Pada Pengumuman Dividen Interim Tahun Buku 2018. Jurnal Ekonomi Efektif, 2(1).

Rudianto. (2013). Akuntansi Manajemen Informasi Untuk Pengambilan Keputusan Strategis. Jakarta: Erlangga.

Sugiyono. (2015). Metode Penelitian Kombinasi (Mix Methods). Bandung: Alfabeta.

Sugiyono. (2016). Metode Penelitian Kuantitatif, Kualitatif $R \& D$. Bandung: IKAPI.

Sujawerni, V. W. (2017). Analisis Laporan Keuangan. Yogyakarta: Pustaka Baru Press Perpustakaan Nasional RI Katalog Dalam Terbitan (KDT). 
Sujawerni, V. W. (2020). Analisis Laporan Keuangan. Yogyakarta: Pustaka Baru Press Perpustakaan Nasional RI Katalog Dalam Terbitan (KDT).

Sutrisno. (2012). Manajemen Keuangan Teori, Konsep dan Aplikasi. Yogyakarta: EKONISIA.

Wartono, T., Tumanggor, M., Oktrima, B., \& Delimah, V. L. (2021, January).

Analysis of Ratio and Financial Performance of Open Company Pharmaceutical Industry Which has Been Listing in Indonesia Stock Exchange (Case Study in Pharmaceutical Company PT. Kimia Farma. Tbk). In INCEESS 2020: Proceedings of the 1st International Conference on Economics Engineering and Social Science, InCEESS 2020, 17-18 July, Bekasi, Indonesia (p. 268). European Alliance for Innovation. 